\title{
Evaluasi Kepuasan E-commerce Supply Chain Management dari Sisi Kepercayaan dan Kualitas Layanan Konsumen
}

\author{
Eka Sudarusman ${ }^{1 凶}$, Sri Lani $^{2}$, RR. Rani Kusumo Wardhani ${ }^{3}$ \\ Sekolah Tinggi Ilmu Manajemen YKPN Yogyakarta, Indonesia ${ }^{1}$ \\ Universitas Kristen Satya Wacana, Indonesia ${ }^{2}$ \\ Universitas Triatma Mulya, Indonesia ${ }^{3}$ \\ e-mail:922021002@student.uksw.edu
}

\begin{abstract}
Supply Chain Management (SCM), involves various parties, either directly or indirectly, to fulfill customer demands. Manufacturers and suppliers are part of the supply chain, including shipping, warehousing, retailers, as well as the customers themselves. In any organization, the supply chain consists of all the functions involved in receiving and fulfilling customer demands. The main concern of SCM is to provide customers with the right product, at the right cost, at the right time, with the right quality and in the right quantity. This study aims to evaluate the satisfaction of SCM e-commerce in terms of trust and customer service quality. The results show that trust and service quality have a significant positive effect on e-commerce SCM. Service quality partially mediates trust in customer satisfaction.
\end{abstract}

Keywords: SCM, trust, service quality, satisfaction

\begin{abstract}
Abstrak
Supply Chain Management (SCM) melibatkan berbagai pihak, baik secara langsung atau tidak langsung, untuk memenuhi permintaan pelanggan. Produsen dan pemasok menjadi bagian dari rantai pasok yang mencakup pengiriman, pergudangan, pengecer, dan juga pelanggan itu sendiri. Dalam setiap organisasi, rantai pasokan terdiri dari semua fungsi yang terlibat dalam menerima dan memenuhi permintaan pelanggan. Perhatian utama dari SCM adalah menyediakan ketepatan produk kepada pelanggan dengan biaya yang tepat, pada waktu yang tepat, dengan kualitas yang tepat, dan dalam kuantitas yang tepat. Penelitian ini bertujuan untuk mengevaluasi kepuasan SCM e-commerce dari sisi kepercayaan dan kualitas layanan konsumen. Hasil menunjukkan bahwa kepercayaan dan kualitas layanan berpengaruh positif signifikan terhadap SCM e-commerce. Service quality memediasi secara parsial kepercayaan tehadap kepuasan konsumen.
\end{abstract}

Kata kunci: SCM, trust, service quality, satisfaction 


\section{PENDAHULUAN}

Pesatnya perkembangan teknologi informasi menjadikan sebuah jaringan bisnis berubah tanpa batas. Penggunaan dan pemanfaatan internet tidak hanya terbatas pada informasi yang dapat diakses melalui media ini, melainkan juga dapat digunakan sebagai sarana untuk melakukan transaksi perdagangan dengan marketplace baru dan sebuah jaringan bisnis dunia yang luas yang tidak terbatas waktu dan tempat. Berdasarkan hasil survei APJI dan Polling Indonesia, jumlah pengguna internet di Indonesia pada 2018 bertambah 27,91 juta $(10,12 \%)$ menjadi 171,18 juta jiwa. Hal ini berarti penetrasi pengguna internet di Indonesia meningkat menjadi $64,8 \%$ dari total penduduk yang mencapai 264,16 juta jiwa. Berdasarkan spasial, Pulau Jawa masih menjadi wilayah pengguna internet terbesar di Indonesia, yakni mencapai 55\% (Billyarta \& Sudarusman, 2021).

Saat ini, tingkat transaksi online di masyarakat malah mengalami peningkatan. Pada tahun 2020 terjadi kenaikan jumlah transaksi e-commerce sebesar $29,6 \%$ dari Rp 205,5 triliun pada 2019 menjadi Rp 266,3 triliun (Jayani, 2021). Fenomena yang terlihat, di saat pengangguran meningkat, tetapi transaksi e-commerce mengalami peningkatan.

Shawn dan Turbane menyatakan bahwa e-commerce merupakan transaksi paperless, diantaranya pertukaran data elektronik, surat elektronik, papan buletin elektronik, transfer dana elektronik dan teknologi berbasis jaringan lainnya diterapkan berdasarkan jaringan. Umumnya, e-commerce adalah strategi komersial baru yang bertujuan untuk peningkatan kualitas produk dan layanan dan perbaikan di tingkat layanan penyediaan sementara link persyaratan organisasi, pemasok, dan konsumen ke arah efisiensi ataupun pengurangan biaya. Ecommerce merupakan pendekatan baru dalam bisnis, baik secara elektronik dengan menggunakan jaringan maupun internet. Dengan cara ini, proses jual beli atau pertukaran produk, jasa dan informasi melalui komputer melakukan komunikasi dan jaringan termasuk internet (Pradana, 2015).

Pasar e-commerce di Indonesia menjadi sangat potensial seiring dengan perkembangan pengguna internet yang semakin meningkat. Saat ini, transaksi perdagangan elektronik telah menjadi bagian dari gaya hidup masyarakat Indonesia. Beberapa perilaku konsumen di Indonesia telah mengalami perubahan seiring dengan berkembangnya bisnis ecommerce, salah satunya adalah konsumen mulai beralih belanja dengan menggunakan media online. Alternatif konsumen untuk berbelanja di tengah kebiasaan baru adalah dengan layanan e-commerce. Perilaku konsumen berubah dari semula belanjan terencana menjadi 'discovery led' atau mencari-cari barang yang ingin dibeli di platform. Shopee adalah salah satu marketplace yang menjadi pilihan para konsumen. Saat ini, Shopee menjadi salah satu marketplace dengan pengunjung situs bulanan terbesar di Indonesia. Data iPrice menunjukkan, marketplace ini mendapatkan sebanyak 71,5 juta kunjungan selama kuartal I tahun 2020.

Di Indonesia, belanja online sudah umum dilakukan masyarakat untuk mendapatkan barang dengan mudah tanpa menguras banyak waktu dan tenaga. Shopee salah satu situs yang ikut meramaikan pertumbuhan industri e-commerce di Indonesia. Shopee merupakan platform perdagangan elektronik sebagai pelanggan untuk pelanggan $(\mathrm{C} 2 \mathrm{C})$ dan bisnis untuk pelanggan (B2C), sebagai marketplace Shopee memang memanjakan pelanggan dalam hal belanja online., Kedudahan dalam Shopee diantaranya fitur live chat, kemudahan komunikasi antara penjual dan pembeli dan kemudahan dalam mencari produk yang diinginkan. Berbagi (social sharing), hashtag, sistem notifikasi melalui SMS, serta perhitungan ongkos kirim yang otomatis yang memudahkan penjual dan pembeli dalam cek ongkos kirim, sistem akan langsung menghitung ongkos kirim yang ditanggung pembeli, serta pembeli 
diberi keleluasaan dalam memilih kurir yang diinginkan. Shopee juga banyak memberikan program menarik untuk pembeli maupun penjual. Aplikasi Shopee dapat diunduh secara gratis di App Store dan Google Play Store.

Electronic-service quality (e-service quality) adalah suatu tingkat bagaimana sebuah website secara efektif dan efisien memfasilitasi pelanggan dalam hal berbelanja, melakukan pembelian, dan proses penyerahan dari produk dan jasa (Parasuraman dkk., 2005). Pada dasanya, eservice quality merupakan segala bentuk aktifitas yang dilakukan perusahaan guna memenuhi kebutuhan dan harapan konsumen. Ditinjau dari sisi konsumen, kepuasan konsumen yaitu tentang apa yang telah dirasakan atas pelayanan yang telah diberikan dibandingkan dengan apa yang mereka inginkan. Sementara itu, ketidakpuasan timbul apabila hasil yang diinginkan tidak sesuai dengan harapan yang diinginkan. Terdapat tujuh dimensi eservice quality yaitu efisiensi, fulfillment, reliability, privasi, responsiveness, kompensasi, dan kontak (Parasuraman dkk., 1985; Parasuraman dkk., 2005). Pada prinsipnya, model e-service quality ini merupakan adaptasi dan perluasan model tradisional service quality ke dalam konteks pengalaman transaksi jual beli online.

Supply chain management (SCM) menjadi penting untuk meningkatkan kekuatan kompetitif. Perhatian utama SCM adalah menyediakan produk yang tepat kepada pelanggan yang tepat dengan biaya yang tepat, pada waktu yang tepat, dengan kualitas yang tepat dan dalam jumlah yang tepat (Chopra \& Meindl, 2013). Tujuan strategis jangka pendek lainnya dari SCM adalah untuk mengurangi waktu siklus dan persediaan sehingga meningkatkan produktivitas, sedangkan tujuan jangka panjang adalah untuk meningkatkan keuntungan melalui pangsa pasar dan kepuasan pelanggan (Susanty dkk., 2018).

Beberapa penelitian tentang hubungan SCM dengan kepuasan, kualitas layanan, dan kepercayaan konsumen dalam e-commerce menunjukan ada beberapa perbedaan hasil. Penelitian Winastuti (2016) menunjukkan hasil bahwa dimensi kualitas layanan tidak berpengaruh terhadap kepuasan, hanya satu dari tujuh dimensi kualitas layanan yang berpengaruh yaitu dimensi kontak. Sementara itu, Ting dkk. (2016) menemukan bahwa semua dimensi kualitas layanan berpengaruh positif terhadap kepuasan konsumen. Selain itu, Susanty dkk. (2018) menemukan bahwa kepercayaan berpengaruh positif siginifikan terhadap kinerja SCM. Hasil pengujian Firmansyah \& Ali (2019) menunjukkan bahwa kepercayaan berpengaruh langsung dan signifikan terhadap minat membeli kembali sebagai bagian dari retensi pelanggan. Ini berbeda dengan hasil penelitian Ghaderi dkk. (2018), bahwa TSC di Isfahan menunjukkan bahwa wisatawan yang datang tidak puas dengan atraksi (inbond tourist) karena korelasi negatif antara faktor ini dari TSC dan kepuasan wisatawan.

Berdasarkan uraian di atas, maka peneliti terdorong untuk melakukan evaluasi dari kepuasan rantai nilai ecommerce dari sisi kualitas layanan dan kepercayaan konsumen. Salah satu ecommerce yang menjadi pilihan peneliti adalah marketplace Shopee di Yogyakarta.

Supply chain management (SCM), adalah semua pihak yang terlibat, secara langsung atau tidak langsung, dalam memenuhi permintaan pelanggan. Rantai pasokan tidak hanya mencakup produsen dan pemasok, tetapi juga pengiriman, pergudangan/logistik, pengecer, dan bahkan pelanggan itu sendiri. Rantai pasokan dalam sebuah institusi atau organisasi, mencakup semua fungsi yang terlibat dalam menerima dan memenuhi permintaan pelanggan. Fungsi-fungsi ini termasuk, tetapi tidak terbatas pada, pengembangan produk baru, pemasaran, operasi, distribusi, keuangan, dan layanan pelanggan (Chopra \& Meindl, 2013).

Proses SCM termasuk desain produk, sumber bahan, dan seleksi, proses manufaktur, pengiriman produk akhir ke 
konsumen serta penanganan produk pasca pembelian. Tujuan utama SCM adalah untuk memberikan produk yang tepat kepada pelanggan yang tepat dengan biaya yang tepat, waktu yang tepat, kualitas yang tepat, bentuk yang tepat dan kuantitas yang tepat (Mardani dkk., 2020). Sebagian besar rantai pasokan sebenarnya adalah jaringan. Mungkin lebih akurat menggunakan istilah jaringan pasokan atau jaringan pasokan untuk menggambarkan struktur sebagian besar rantai pasokan.

Kepercayaan menciptakan perasaan yang menguntungkan terhadap penjual yang cenderung meningkatkan niat pelanggan untuk membeli produk dari penjual. Kepercayaan dipandang sebagai seperangkat keyakinan khusus yang berhubungan terutama dengan kebajikan, kompetensi, dan integritas pihak lain. Kebajikan adalah keyakinan bahwa penjual tidak akan bertindak secara oportunistis terhadap pembeli, bahkan jika diberi kesempatan. Kompetensi adalah keyakinan akan kemampuan penjual untuk memenuhi kewajibannya seperti yang diharapkan oleh pembeli. Integritas adalah keyakinan bahwa penjual akan jujur dan menghormati komitmennya (Firmansyah \& Ali, 2019).

Kepercayaan elektronik konsumen (etrust) sebagian besar dikaitkan dengan kepercayaan melalui internet dan terutama dengan e-commerce (Tran \& Vu, 2019; Firmansyah \& Ali, 2019). Kepercayaan elektronik tergantung pada jaminan keamanan, reputasi, pencarian web, pemenuhan (misalnya, kesediaan untuk menyesuaikan), presentasi (misalnya, kualitas web), teknologi, dan interaksi (misalnya, forum elektronik) (Al-dweeri dkk., 2017). Kepercayaan konsumen pada internet secara online terjadi ketika konsumen mulai terangsang oleh kebutuhannya dan makin merasa penasaran dalam usaha mencari informasi untuk mendapatkan apa yang konsumen inginkan. Perhatian utama seorang pemasar adalah sumber informasi yang menjadi acuan konsumen dan keputusan pembelian sebagai pengaruh kuat dari masing-masing sumber. Sebuah transaksi komersial antara pelanggan dan penjual, kepercayaan menjadi peran kunci, terutama di lingkungan online dimana tidak ada interaksi tatap muka.

E-service quality didefinisikan secara luas adalah bagaimana sebuah website secara efektif dan efisien memfasilitasi pelanggan dalam hal berbelanja, melakukan pembelian, dan proses penyerahan atau pengiriman produk dan jasa (Parasuraman dkk., 2005; Cetinsoz, 2015). E-service quality dipakai sebagai sarana untuk mengukur persepsi pelanggan terhadap kualitas jasa yang disampaikan pengecer online. E-service quality didasarkan pada arus informasi timbal balik antara pelanggan dan penyedia layanan, membuatnya berbeda dari layanan tradisional. E-service quality tinggi memiliki banyak keuntungan dan dapat mengarah pada efisiensi dan manfaat (Shafiee \& Bazargan, 2018).

E-service quality dapat digambarkan sebagai persepsi pelanggan secara keseluruhan atau evaluasi pengalaman layanan elektronik dari pasar online. Eservice quality dalam e-commerce dapat didefinisikan sebagai evaluasi dan penilaian konsumen secara keseluruhan terhadap keunggulan dan kualitas layanan elektronik yang ditawarkan di pasar virtual. Ada beberapa perbedaan utama antara layanan tradisional dan layanan elektronik. Juga, ada perbedaan antara layanan mandiri dan layanan elektronik. Perbedaan antara layanan tradisional dan layanan elektronik adalah sebagai berikut. Dalam service quality tradisional, hanya orang (karyawan) yang terlibat dalam antar muka pertemuan layanan. Di sisi lain, dalam layanan elektronik, TIK atau karyawan terlibat dalam antar muka, dimediasi oleh internet. Selain itu, selama pertemuan e-service, pelanggan dibatasi untuk mendengar dan melihat, sedangkan dalam layanan tradisional, pelanggan dapat merasakan layanan dengan menggunakan semua indra merek (Firmansyah \& Ali, 2019; Shafiee \& Bazargan, 2018). 
Dimensi-dimensi ini meliputi pula kriteria yang digunakan pelanggan untuk mengevaluasi layanan online rutin manakala mereka tidak mengalami masalah sehubungan dengan penggunaan situs tertentu. Secara ringkas, tujuh dimensi eservice quality meliputi: efficiency, fulfillment, reliability, privacy, responsiveness, compensation, dan contact (Parasuraman dkk., 2005; Tjiptono \& Chandra, 2019).

Menurut Tjiptono \& Chandra (2019), kata kepuasan (satisfaction) berasal dari kata "satis" yang berarti cukup baik atau memadai dan "facio" yang berarti melakukan atau membuat. Kepuasan konsumen adalah tingkat perasaan seseorang setelah melakukan perbandingan (kinerja atau hasil) yang dirasakan dibandingkan dengan harapan yang dinginkan (Kotler \& Armstrong, 2012). Tiga tingkat kepuasan konsumen yaitu ketika kinerja di bawah harapan, maka konsumen akan merasa kecewa, tetapi bilamana kinerja sesuai dengan harapan, maka pelanggan akan merasa puas dan apabila kinerja bisa melebihi harapan maka pelanggan akan merasakan sangat puas, senang, atau gembira.

Kepuasan secara elektronik (esatisfaction) adalah hasil dari pengalaman dan kepuasan secara keseluruhan mengenai situs web vendor elektronik tertentu (Giao dkk., 2020). Ini melambangkan kepuasan pelanggan sehubungan dengan pengalaman pembelian mereka sebelumnya dengan perusahaan perdagangan elektronik tertentu. Penilaian pengalaman online pelanggan memainkan peran penting dalam e-commerce.

Kepuasan adalah perasaan senang atau kecewa dari seseorang yang membandingkan suatu produk atau kinerja yang dirasakan (atau hasil) layanan dengan harapan yang diniginkan. Jika kinerja atau pengalaman kurang dari harapan, maka pelanggan tidak puas. Pelanggan akan merasa puas jika sesuai dengan harapan mereka. Jika melebihi harapannya, maka pelanggan sangat puas atau senang (Keller,
2016). Pelanggan yang dinyatakan puas akan melakukan hal-hal seperti menggunakan jasa itu kembali dan pelanggan tidak pernah mengeluh.

\section{Hubungan antara Kepercayaan dan Kepuasan Konsumen}

Aspek utama kepercayaan mengacu pada keandalan dan keyakinan pada sesuatu. Kepercayaan memainkan peran kunci dalam transaksi komersial antara pelanggan dan penjual, terutama di lingkungan online dimana tidak ada interaksi tatap muka. Kepercayaan elektronik konsumen (e-trust) sebagian besar dikaitkan dengan kepercayaan melalui internet dan terutama dengan e-commerce (Tran \& Vu, 2019). Kepercayaan memainkan peran kunci dalam transaksi komersial antara pelanggan dan vendor, terutama di lingkungan online di mana tidak ada interaksi tatap muka (Firmansyah \& Ali, 2019). Kepuasan konsumen dapat dilihat dari sejauh mana konsumen memiliki kepercayaan terhadap proses transaksi.

$\mathrm{H}_{1}$ : Kepercayaan elektronik konsumen (etrust) dalam rantai nilai e-commerce berpengaruh positif terhadap kepuasan konsumen elektronik (e-satisfaction),

\section{Hubungan antara Kualitas Layangan dan Kepuasan Konsumen}

Kualitas layanan mengarah pada potensi keuntungan strategis, seperti peningkatan loyalitas pelanggan dan pertumbuhan dalam operasi perusahaan, efisiensi dan profitabilitas (Kaya dkk., 2019). Sangat penting untuk memahami kualitas layanan dalam domain e-commerce, dan apa yang dihargai konsumen dalam transaksi berbasis web. E-service quality digunakan untuk mengukur persepsi pelanggan terhadap kualitas jasa yang disampaikan pengecer secara online (Shafiee \& Bazargan, 2018). Kepuasan secara elektronik (e-satisfaction) adalah hasil dari pengalaman dan kepuasan secara keseluruhan mengenai situs web vendor elektronik tertentu (Giao dkk., 2020). Penilaian pengalaman online 
pelanggan memainkan peran penting dalam e-commerce.

$\mathrm{H}_{2}$ : Kualitas layanan elektronik (eservqual) dalam rantai nilai ecommerce berpengaruh positif terhadap kepuasan konsumen elektronik (e-satisfaction).

$\mathrm{H}_{3}$ : Kualitas layanan elektronik (eservqual) memediasi kepercayaan elektronik konsumen (e-trust) dalam rantai nilai e-commerce.

\section{METODE PENELITIAN}

Penelitian ini merupakan penelitian dengan menggunakan pendekatan kuantitatif. Jenis penelitian adalah penelitian studi kasus dengan tujuan menguji teori dan memberikan bukti empiris. Populasi dalam penelitian ini adalah warga yang berdomisili di Yogyakarta, yang terdiri dari empat kabupaten yaitu Kabupaten Sleman, Kabupaten Kulonprogo, Kabupaten Bantul, dan Kabupaten Gunung Kidul, dan satu kota madya, yaitu Kota Yogyakarta.

Dalam penelitian ini terdapat 13 indikator sehingga jumlah sampel yang digunakan dalam adalah sebesar 130 responden (Hair dkk., 2019). Teknik pengambilan data yang digunakan peneliti adalah kuesioner, dengan menggunakan skala pengukuran yaitu skala Likert yang terdiri dari lima kategori. Terdapat 50 pertanyaan dari 13 indikator penelitian. Dalam penelitian ini teknik pengambilan sampel yang digunakan adalah menggunakan metode non probability sampling, dengan teknik purposive sampling. Dalam penelitian ini, sampel yang diambil adalah warga yang berdomisili di Yogyakarta dengan minimal transaksi sebanyak dua kali. Kuesioner yang terkumpul sejumlah 237 .

Uji hipotesis menggunakan model analisis mediasi (path analysis) untuk mengetahui apakah variabel berperan dalam memediasi. Dengan cara melakukan regresi sederhana pada variabel $X$ terhadap variabel $\mathrm{Y}$, variabel $\mathrm{X}$ terhadap variabel mediator $(\mathrm{M})$, variable $\mathrm{M}$ terhadap variabel
$\mathrm{Y}$, serta variabel $\mathrm{X}$ dan variabel $\mathrm{M}$ terhadap Variabel Y.

Pada hasil uji hipotesis, variabel mediasi berperan sebagai pemediasi sempurna (perfect mediation) ketika setelah variabel mediasi dimasukkan, pengaruh variabel $\mathrm{X}$ terhadap $\mathrm{Y}$ mengalami penurunan menjadi nol $\left(c^{\prime}=0\right)$ atau pengaruh variabel $\mathrm{X}$ terhadap $\mathrm{Y}$ yang semula signifikan (sebelum variabel mediasi dimasukkan) menjadi tidak signifikan setelah memasukkan variabel mediasi ke dalam model persamaan regresi. Variabel mediasi sebagai pemediasi parsial (partial mediation) terjadi bila setelah variabel Mediasi dimasukkan, pengaruh variabel $\mathrm{X}$ terhadap $\mathrm{Y}$ mengalami penurunan tetapi tidak menjadi nol $\left(c^{\prime} \neq 0\right)$ atau pengaruh variabel $\mathrm{X}$ terhadap $\mathrm{Y}$ yang semula signifikan (sebelum variabel mediasi dimasukkan) tetap signifikan setelah memasukkan variabel mediasi ke dalam model persamaan regersi namun koefesien regresi mengalami penurunan

\section{HASIL DAN PEMBAHASAN}

Berdasarkan hasil perhitungan dapat dilihat bahwa dari pengujian pertama hasil validitas diskriminan ada satu indikator yang memiliki nilai dibawah 0,7 , yaitu indikator efisiensi dengan nilai sebesar 0,278 (Tabel 1). Pada pengujian yang kedua, indikator efisiensi dihilangkan dan hasil validitas diskriminan semua indikator memiliki nilai di atas 0,7 (Tabel 2), sehingga 12 indikator memiliki kemampuan untuk menjelaskan variabel.

Berdasarkan perhitungan uji reliabilitas diperoleh hasil nilai Cronbach's alpha lebih besar dari 0,81, sedangkan jika menggunakan hasil nilai composite reliability semua hasil lebih besar dari 0,7 (Tabel 3). Dengan demikian, instrumen yang digunakan adalah reliable. 
Evaluasi Kepuasan E-commerce Supply Chain ... Layanan Konsumen (Sudarusman, Lani, Wardhani)

Tabel 1. Validitas Ddiskriminan

\begin{tabular}{lccc}
\hline & E-SATF & E-SERVQ & E-TRUST \\
\hline EKN & & 0,278 & \\
ERS & & 0,985 & \\
ESE & & 0,807 & \\
ESF & & 0,815 & \\
ESK & & 0,862 & \\
ESP & & 0,802 & \\
ESR & & 0,891 & \\
SA1 & 0,899 & & \\
SA2 & 0,909 & & \\
SA3 & 0,775 & & 0,843 \\
TR1 & & & 0,937 \\
TR2 & & & 0,873 \\
TR3 & & & \\
\hline
\end{tabular}

Tabel 2. Validitas Diskriminan tanpa Indikator Efisiensi

\begin{tabular}{lccc}
\hline & E-SATF & E-SERVQ & E-TRUST \\
\hline ERS & & 0,987 & \\
ESE & & 0,806 & \\
ESF & & 0,820 & \\
ESK & & 0,863 & \\
ESP & & 0,809 & \\
ESR & & 0,891 & \\
SA1 & 0,899 & & \\
SA2 & 0,909 & & \\
SA3 & 0,775 & & 0,842 \\
TR1 & & & 0,938 \\
TR2 & & & 0,874 \\
TR3 & & & \\
\hline
\end{tabular}

Tabel 3. Hasil Uji Reliabilitas

\begin{tabular}{lcccc}
\hline & $\begin{array}{c}\text { Cronbach's } \\
\text { Alpha }\end{array}$ & rho_A & $\begin{array}{c}\text { Composite } \\
\text { Reliability }\end{array}$ & $\begin{array}{c}\text { Average Variance } \\
\text { Extracted (AVE) }\end{array}$ \\
\hline E SATISFACTION (Y) & 0,829 & 0,857 & 0,897 & 0,745 \\
E SERVQUAL (X2) & 0,931 & 0,939 & 0,947 & 0,748 \\
E TRUST (X1) & 0,863 & 0,901 & 0,916 & 0,784 \\
\hline
\end{tabular}

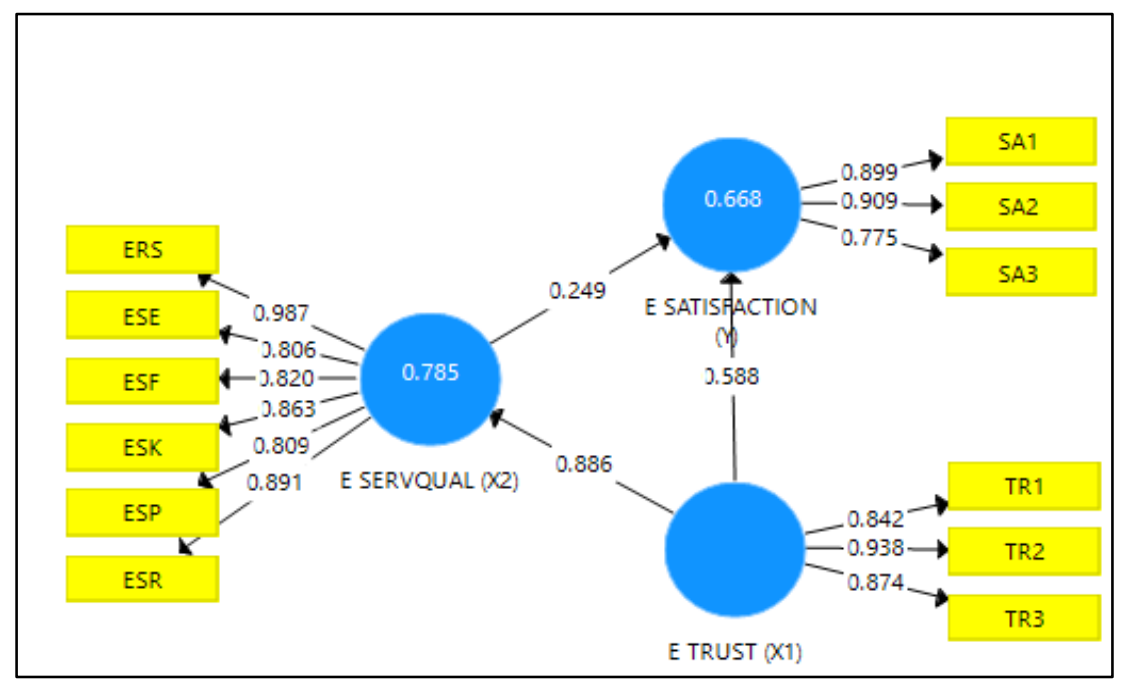

Gambar 1. Hasil Uji Analisis Jalur

Tabel 4. Path coefficient

\begin{tabular}{lccccc}
\hline & $\begin{array}{c}\text { Original } \\
\text { Sample } \\
(\mathrm{O})\end{array}$ & $\begin{array}{c}\text { Sample } \\
\text { Mean } \\
(\mathrm{M})\end{array}$ & $\begin{array}{c}\text { Standard } \\
\text { Deviation } \\
(\text { STDEV })\end{array}$ & $\begin{array}{c}\text { T Statistics } \\
(|\mathrm{O} / \mathrm{STDEV}|)\end{array}$ & $\begin{array}{c}\mathrm{P} \\
\text { Values }\end{array}$ \\
\hline E SERVQUAL (X2) -> E SATISFACTION $(\mathrm{Y})_{-}$ & 0,249 & 0,249 & 0,089 & 2,787 & 0,006 \\
E TRUST (X1) -> E SATISFACTION (Y)_- & 0,588 & 0,588 & 0,087 & 6,769 & 0,000 \\
E TRUST (X1) -> E SERVQUAL (X2) & 0,886 & 0,886 & 0,014 & 64,153 & 0,000 \\
\hline
\end{tabular}

Tabel 5. Pengaruh Tidak Langsung

\begin{tabular}{cccccc}
\hline & $\begin{array}{c}\text { Original } \\
\text { Sample } \\
(\mathrm{O})\end{array}$ & $\begin{array}{c}\text { Sample } \\
\text { Mean } \\
(\mathrm{M})\end{array}$ & $\begin{array}{c}\text { Standard } \\
\text { Deviation } \\
(\mathrm{STDEV})\end{array}$ & $\begin{array}{c}\text { T Statistics } \\
(|\mathrm{O} / \mathrm{STDEV}|)\end{array}$ & $\begin{array}{c}\mathrm{P} \\
\text { Values }\end{array}$ \\
\hline $\begin{array}{c}\text { E TRUST (X1) -> E SERVQUAL (X2) -> } \\
\text { E SATISFACTION (Y)_ }\end{array}$ & 0,221 & 0,221 & 0,080 & 2,742 & 0,006 \\
\hline
\end{tabular}


Hasil pengujian model menunjukkan hasil Standardized Root Mean Square Residual (SMSR) adalah sebesar 0,079 yang nilai lebih kecil dari 0,1 . Sementara nilai Normal Fit Index (NFI) sebesar 0,725. Nilai NFI adalah antara 0 dan 1 . Nilai SMSR dan NFI yang mendekati nilai 1 , menunjukkan model tersebut bisa digunakan untuk pengamatan. Dengan demikian dapat disimpulkan bahwa seluruh instrumen dari tiga variabel tersebut konsisten dan reliable digunakan sebagai instrumen penelitian.

Hasil pengujian dengan analisis jalur (path analysis) menunjukkan bahwa X1 berpengaruh posistif dan siginfikan terhadap Y, X2 berpengaruh posistif dan siginfikan terhadap $\mathrm{Y}$, dan $\mathrm{X} 1$ berpengaruh posistif dan siginfikan terhadap $\mathrm{X} 2$. Pengaruh positif ditunjukkan dari nilai original sample yang semuanya bernilai positif dan nilai p-value yang lebih kecil dari 0,05. Dengan demikian hipotesis penelitian $\mathrm{H}_{1}, \mathrm{H}_{2}$, dan $\mathrm{H}_{3}$ terbukti.

Pengujian secara tidak langsung menunjukkan bahwa X1 terhadap X2 terhadap $\mathrm{Y}$, menunukkan positif signifikan. Hal tersebut ditunjukkan dengan nilai original sample yang bernilai positif dan pvalues yang lebih kecil dari 0,05 (Tabel 5). Dengan demikian hipotesis penelitian $\mathrm{H}_{3}$ terbukti.

Besarnya pengaruh variabel $\mathrm{X} 1$ dan X2 terhadap Y adalah sebesar 0,668, yang berarti kepercayaan konsumen dan kualitas layanan mempengaruhi kepuasan konsumen sebesar 66,8\%, sedangkan sebelihnya dipengaruhi oleh variabel lain. Besarnya pengaruh kepercayaan terhadap kualitas layanan adalah 78,5\% (Gambar 1).

\section{SIMPULAN DAN SARAN}

Hasil pengujian menunjukkan bahwa variabel independen (X1) dan variabel mediasi (X2) memiliki pengaruh positif signifikan dalam rantai pasok e-commerce. Hal tersebut ditunjukkan dengan nilai koefisien regresi yang positif dengan pvalue yang lebih kecil dari 0,05. Pengaruh langsung (direct effect coef.) dari e-trust terhadap kepuasanan adalah sebesar 0,588, sedangkan pengaruh tidak lansung (indirect effect coef.) e-trust terhadap kepuasanan yang dimediasi oleh e-service quality adalah sebesar 0,221. Dari hasil tersebut dapat disimpulkan bahwa, baik secara langsung maupun tidak langsung, e-trust dan e-service quality memiliki efek positif. Hasil koefisien regresi yang menurun menunjukkan bahwa e-service quality memediasi secara parsial.

Hasil ini sejalan dengan penelitian Ting dkk. (2016) bahwa semua dimensi kualitas layanan berpengaruh positif terhadap kepuasan konsumen. Hasil pengujian hipotesis Susanty dkk. (2018) menunjukkan bahwa kepercayaan berpengaruh positif siginifikan terhadap kinerja SCM. Selain itu, sesuai dengan Firmansyah \& Ali (2019), kepercayaan berpengaruh langsung dan signifikan terhadap minat membeli kembali sebagai bagian dari retensi pelanggan.

Besar koefisien determinasi sebesar 0,668 menunjukkan hubungan keeratan bahwa kepuasan dijelaskan oleh e-trust (X1) sebesar 66,8\%. Koefisien determinasi sebesar 0,785 menunjukkan hubungan keeratan bahwa e-serqual (X2) sebagai variabel mediasi dapat dijelaskan oleh etrust (X1) sebear 78,5\% sebagai variabel independen.

\section{REFERENSI}

Al-dweeri, R. M., Obeidat, Z. M., Al-dwiry, M. A., Alshurideh, M. T., \& Alhorani, A. M. (2017). The impact of e-service quality and eloyalty on online shopping: moderating effect of e-satisfaction and e-trust. International Journal of Marketing Studies, 9(2), 92103.

Billyarta, G. W., \& Sudarusman, E. (2021). Pengaruh Kualitas Layanan Elektronik (E-Servqual) terhadap Kepuasan Konsumen pada Market Place Shopee di Sleman DIY. Jurnal Optimal, 18(1), 41-62. 
Evaluasi Kepuasan E-commerce Supply Chain ... Layanan Konsumen (Sudarusman, Lani, Wardhani)

Cetinsoz, B. C. (2015). The influence of eservice quality on customer perceived value: A study on domestics tourists in Turkey. International journal of science and research, 4(1), 12651677.

Chopra, S., \& Meindl, P. (2013). Strategy, planning, and operation. Supply Chain Management, Fifth ed. New Jersey: Pearson Education.

Firmansyah, N., \& Ali, H. (2019). Consumer Trust Model: The Impact of Satisfaction and EService Quality toward Repurchase Intention in ECommerce. Saudi Journal of Humanities and Social Sciences, 4(8), 552-559.

Ghaderi, Z., Hatamifar, P., \& Khalilzadeh, J. (2018). Analysis of tourist satisfaction in tourism supply chain management. Anatolia, 29(3), 433-444.

Giao, H., Vuong, B., \& Quan, T. (2020). The influence of website quality on consumer's e-loyalty through the mediating role of e-trust and esatisfaction: An evidence from online shopping in Vietnam. Uncertain Supply Chain Management, 8(2), 351-370.

Hair, J. F., Black, W. C., Babin, B. J., \& Anderson, R. E. (2019). Multivariate data analysis (Eighth $E d$.). Cengage, Andover.

Jayani, D. H. (2021). Nilai Transaksi ECommerce Mencapai Rp 266,3 Triliun pada 2020. Databoks. Diakses dari https://databoks. katadata.co.id/datapublish/2021/0 1/29/nilai-transaksi-e-commercemencapai-rp-2663-triliun-pada2020.

Kaya, B., Behravesh, E., Abubakar, A. M., Kaya, O. S., \& Orús, C. (2019). The moderating role of website familiarity in the relationships between e-service quality, esatisfaction and e-loyalty. Journal of Internet Commerce, 18(4), 369394.

Keller, P. (2016). Marketing Management, Global Edition. Pearson Education Limited.

Kotler, P., \& Armstrong, G. (2012). Principles of Marketing, 14th Edition. Pearson Prentice Hall.

Mardani, A., Kannan, D., Hooker, R. E., Ozkul, S., Alrasheedi, M., \& Tirkolaee, E. B. (2020). Evaluation of green and sustainable supply chain management using structural equation modelling: A systematic review of the state of the art literature and recommendations for future research. Journal of cleaner production, 249, 119383.

Parasuramam, A., Zeithaml, V. A., \& Berry, L. L. (1985). A conceptual model of service quality and its Service quality perspectives and Customer implications for future research. Journal of Marketing, satisfaction in commercial banks working in Jordan, 49, 41-50.

Parasuraman, A., Zeithaml, V. A., \& Malhotra, A. (2005). E-S-QUAL: A Multiple-Item Scale for Assessing Electronic Service Quality. Journal of Service Research, 7(3), 213-233.

Pradana, M. (2015). Pemasaran Digital: Adopsi Media Sosial Pada UKM. Klasifikasi Bisnis E-Commerce Di Indonesia, 27(1), 174.

Shafiee, M. M., \& Bazargan, N. A. (2018). Behavioral customer loyalty in online shopping: the role of eservice quality and e-recovery. Journal of theoretical and applied electronic commerce research, 13(1), 26-38.

Susanty, A., Sirait, N. M., \& Bakhtiar, A. (2018). The relationship between information sharing, informal contracts and trust on performance of supply chain management in the SMEs of batik. Measuring 
Business Excellence, 22(3), 292314.

Ting, O. S., Ariff, M. S. M., Zakuan, N., Sulaiman, Z., \& Saman, M. Z. M. (2016). E-service quality, esatisfaction and e-loyalty of online shoppers in business to consumer market; Evidence form Malaysia. In IOP Conference Series: Materials Science and Engineering (Vol. 131, No. 1, p. 012012). IOP Publishing.

Tjiptono, F., \& Chandra, G. (2019). Service, Quality \& Customer Satisfaction, Edisi 5. Yogyakarta: ANDI.
Tran, V. D., \& Vu, Q. H. (2019). Inspecting the relationship among E-service quality, E-trust, E-customer satisfaction and behavioral intentions of online shopping customers. Global Business \& Finance Review (GBFR), 24(3), 29-42.

Winastuti, E. D. (2016). Pengaruh EService Quality terhadap Kepuasan Pengguna OLX Mobile di Yogyakarta. Skripsi. Sekolah Tinggi Ilmu Manajemen YKPN Yogyakarta. 